\title{
Trump: Causes and Consequences (the Sequel)
}

\author{
Michael Bernhard and Daniel O'Neill
}

0 ince the first installment of our exploration of the causes and consequences of the Trump presidency, the Mueller Report has been, in part, made public. It did not resolve as much as either the president's supporters or detractors had hoped. The former seized on it as a full vindication, echoing the president's ceaseless claims of "no collusion, no obstruction!" in the wake of Attorney General Barr's exculpatory summary and subsequent unalloyed defenses of the nation's chief executive. For the latter, it meant anything from disappointment, to a need for further congressional investigations, to the evidentiary record for impeachment on charges of obstruction of justice. Many Democrats have been wary of the new attorney general, not least because he had earlier penned a memo outlining an extraordinarily expansive view of executive power that cast doubt on whether he believed a sitting president could even commit obstruction of justice in the first place, and because he had also presided over the pardons of a number of Reagan-era officials convicted as a result of the Iran-Contra investigations earlier in his career. Emboldened by the actions of Barr and Republican support in Congress, President Trump has subsequently decided that "fighting all the subpoenas" issued by House Democrats aimed at any legislative oversight of his administration and claiming blanket executive privilege over the Mueller report is the best way forward for the republic, thereby creating a fundamental battle over separation of powers and raising the specter of a constitutional crisis. Given the unprecedented pace of news in the past two plus years of the Trump presidency, no doubt by the time this issue comes to press there will be an entirely new set of heretofore unthinkable political actions to discuss.

In the face of this, political science and political scientists labor on, trying to understand what it all means. This issue, like the prior one, opens with a selection of pieces which offer explanations for how President Trump won the 2016 election. In our first article, "The Hillary Hypothesis: Testing Candidate Views of Loss," Michael Lewis-Beck and Stephen Quinlan test whether democratic nominee Hillary Clinton's explanation for her loss conforms to reality. Relying on her memoir, What Happened, they show that her social and economic insights on why she lost ring true. However, they find little evidence that Republican harping on her use of a private email server for official business as Secretary of State or James Comey's intervention into that investigation in October cost her the oval office.

Clinton's loss is further probed in Michael Sances' "How Unusual was 2016? Flipping Counties, Flipping Voters, and the Education-Party Correlation since 1952?" Sances focuses on two widely accepted causes of the Trump victory: that counties that voted for Barack Obama flipped for Trump in 2016 and that white voters with low levels of education also switched allegiances in 2016. Sances shows that the number of county-flips was not all that different from past elections, even in pivotal Midwest states that changed from blue to red. Contrarily, the partisan divide by education was at record levels in 2016. He then runs a series of counterfactual analyses to tease out the relative impact of these changes. If the counties that flipped in 2016 had not done so, Hillary Clinton would have won the Electoral College by three votes. However, if the lowest-educated twenty percent of voters had voted by party in 2016 as they had in 2012, the democratic margin in the Electoral College would have been thirty votes. It seems that the education explanation trumps the countyflipping theory.

Finally, Tehama Lopez Bunyasi examines the importance of white resentment in the 2016 Republican primaries. Making use of a unique data-source, the "National Study of Color-Blindness and Race-Consciousness," administered two weeks before the Iowa Caucus, she not only finds that Donald Trump is the most popular candidate among whites in the sample, but that his support grows among those who feel that being white disadvantages them to blacks on the job market. She thus demonstrates that the construction of whiteness as an aggrieved social attribute was key to the president's early electoral success.

The issue also includes several articles on the consequences of the Trump presidency and these explore a variety of subjects such as the state of American democracy, the future of conservatism and the 
Republican Party, and American foreign policy. Among political scientists the Trump presidency has provoked fear that the United States is among the set of countries experiencing "democratic backsliding" in the wake of the Great Recession. Our first article in the consequences section, "Searching for Bright Lines in the Trump Presidency," reports on the first year and half of the surveys conducted by Bright Line Watch. John Carey, Gretchen Helmke, Brendan Nyhan, Mitchell Sanders, and Susan Stokes analyze expert and public opinion surveys that the project periodically fields to understand how citizens and experts evaluate the performance of American democracy. The questions focus on whether politicians are transgressing the established limits of power, potentially undermining the self-enforcing character of the system. While expert opinion is strongly concerned about the erosion of democratic values and practices, public opinion is much more divided along increasingly polarized partisan lines.

In "Conservatism in the Age of Trump," Michael Barber and Jeremy Pope explore ideological differences between Republican voters who fervently support President Trump, those who only supported him in the general election, and those who did not support him. The "Never Trump" camp is the least conservative on some dimensions, yet at the same time these partisans are best able to articulate how they understand what it means to be conservative. Core Trump supporters are precisely the opposite-more conservative in many beliefs but less capable of expressing what it means to be conservative. The piece shows that the Republican Party, despite defining itself as conservative, is not unified in understanding what that means.

Rachel Blum and Christopher Sebastian Parker also examine intra-Republican differences but focus on foreign policy. In "Trump-ing Foreign Affairs: Status Threat and Foreign Policy Preferences on the Right" they find differences between "conventional conservatives" and Trump supporters. Using both survey data on Republican Primary voters and delegates to Republican state conventions, they find that the kind of status threat anxieties that many have used to explain Trump voters extend to their understanding of the place of the United States in the world and their corresponding "America First" foreign policy preferences.

Divisions within the Republican Party, in this case the congressional delegation, are also the focus of "Adversaries or Allies? Donald Trump's Republican Support in Congress" by Jordan Ragusa, Karyn Amira, Lauren Johnson, and Deon McCray. Using data on presidential support back to 1969 they forecast the kind of congressional support that Donald Trump should have expected to enjoy in his first year based on historical projection. They find that his levels of support from his co-partisans in Congress are consistent with this set of expectations. In the second half of the paper they explore the sources of intraparty divisions over support of the president at the level of individual legislators. Here they find that female legislators, those representing affluent districts, and those with higher non-white district populations were more likely to defect, while traditional and establishment conservatives were the most consistent Trump supporters, contradicting those who argued that the party establishment was slow to embrace the new president.

Questions of partisanship and information are central to "Collision with Collusion: Partisan Reaction to the Trump-Russia Scandal," authored by Joshua Darr, Nathan Kalmoe, Kathleen Searles, Mingxiao Sui, Raymond Pingree, Brian Watson, Kirill Bryanov, and Martina Santia. This experimental study looks at repeated exposure to news headlines on the Trump-Russia scandal among Democrats, Republicans, and independents. They find that more frequent exposure to Trump-Russia headlines led to strong negative reactions toward the president among Republicans, even exceeding those of Democrats and independents. The theoretical takeaway is that intense news can overcome partisanship in affecting the evaluation of politicians.

The final piece in this issue is a reflection by Joanna Didi Kuo entitled, "Comparing America: Reflections on Democracy across Subfields." This contribution takes up the theme of democratic decline in the contemporary United States and argues for the use of tools from comparative politics to understand this problem. Kuo advocates for cross-national comparison of the United States to other democracies, and argues for the utility of bodies of theory, developed and more commonly deployed in comparative politics, to reduce distance between the subfields. In as much as comparative politics borrowed quite a bit of theory from American politics during the period of the global expansion of democracy in the 1970s, 1980s, and 1990 s, it seems appropriate for a countermovement to emerge in an age of democratic backlash. Perspectives has always stood for an exchange of ideas and viewpoints across subfields in the discipline. The extent to which we do not have to reinvent the wheel when a new problem grabs our attention in one subfield, and can deploy and adapt the ideas of our colleagues from other subfields, serves to enhance our ability to come together as a field of study. This is something needed now more than ever in order to make sense of the times in which we live. 